Per Espen Akselsen (f. 1956) er overlege ved Seksjon for pasientsikkerhet, Forsknings- og utviklingsavdelingen, Haukeland universitetssjukehus. Ingen oppgitte interessekonflikter.

Litteratur

1. Hofmo PO. Hjelp bøndene i kampen mot MRSA. Tidsskr Nor Legeforen 2016 136: 1065

2. Folkehelseinstituttet. https://www.fhi.no/globalassets/migrering/dokumenter/ pdf/informasjon-om-testing-for-mrsa-av-personer-i-kontakt-medsvinebesetninger-juli-2015-pdf.pdf (1.8.2016).

3. Lov om vern mot smittsomme sykdommer. Avd I 1994 Nr. 16. https://lovdata.no/ dokument/NL/lov/1994-08-05-55 (22.8.2016)

4. Bekjempelse av LA-MRSA - oppfølging av personer som arbeider svinebesetninger. Rundskriv I-2 (2015). Oslo: Helse- og omsorgsdepartementet. https://www.regjeringen.no/contentassets/

63cc6c4c18bd4908b87820ac2b22817e/rundskriv_i2-15_mrsa.pdf (1.8.2016).

\section{Re: På tide å innføre spesialisteksamen}

I Tidsskriftet nr. 12-13/2016 argumenterer Lasse Braathen for å innføre spesialisteksamen i Norge (1). Jeg vil sterkt støtte forslaget. Som Braathen har jeg erfaring som lege og professor både fra Norge og utlandet. For å få spesialistgodkjenning i pediatri i USA (board certification) tok jeg først spesialisteksamen i dette faget, ennskjønt jeg alt var godkjent spesialist i Norge. Etter gjennomført subspesialitetsutdanning i nyfødtintensivmedisin tok jeg deretter «board-eksamen» også på dette området. I det amerikanske systemet kreves så fornyet prøve hvert syvende år.

På bakgrunn av denne erfaringen vil jeg først argumentere for nytten av å måtte tvinge seg selv til å pugge fagene $\mathrm{i}$ hele sin bredde, nettopp med den hensikten å bestå eksamen. Selv om jeg hadde lest under min spesialistutdanning i Norge, opplevde jeg likevel at den helt nødvendige lesingen til eksamen ga et løft i kunnskapsbredde og oversikt som jeg senere har funnet svært nyttig.

Mitt andre argument for spesialisteksamen har med legitimitet og troverdighet å gjøre. Samfunnet forventer med rette at en som praktiserer som lege har fått sin kunnskap og sine ferdigheter testet og bekreftet, slik det skjer gjennom grunnutdanningen i medisin. Det samme gjelder, vil jeg tro, på alle andre områder av høyere utdanning. Det framstår derfor som en selvmotsigelse at man kan godkjennes som spisskompetent på et felt uten, for å formulere det litt karikert, å ha gjort så mye annet enn å møte fram på jobb i tilstrekkelig grad, gjennomført et relativt beskjedent antall kurstimer - mye av det uten krav til å dokumentere at man faktisk har lært noe, og i rimelig grad «oppført seg som folk». Dog må man heldigvis på noen områder, f.eks. kirurgi, legge frem lister som viser at man har fått innøvd i tilstrekkelig omfang de ferdighetene som forventes på feltet.

Foregående må ikke misforstås som en påstand om at norske spesialister «ikke kan noe». Heldigvis har jeg gjennom mange år som lege hatt gleden av å observere at norske spesialister er både kunnskapsrike, dyktige og svært arbeidsomme både i sin praksis og sine studier. Det gjelder definitivt på mitt eget felt barnemedisinen. For det store flertallet vil en spesialisteksamen ikke utgjøre noe hinder. Men den vil gi den enkelte et faglig løft, og den vil gi en formell legitimitet som mangler $i$ vårt nåværende system.

\section{Thor Willy Ruud Hansen}

t.w.r.hansen@medisin.uio.no

Thor Willy Ruud Hansen (f. 1946) er professor i pediatri ved Universitetet i Oslo og overlege ved Nyfødtavdelingen, Kvinne- og barneklinikken, Oslo universitetssykehus.

Ingen oppgitte interessekonflikter.

\footnotetext{
Litteratur

1. Braathen LR. På tide å innføre spesialisteksamen. Tidsskr Nor Legeforen 2016; 136: 1067
}

\section{Re: Olaf Bulls dikt Metope - lest som en terapeutisk samtale}

Njål Flem Mæland har i Tidssskriftet nr. 12-13/2016 (1) en presentasjon og hyllest av Olaf Bull og hans dikt Metope. Han skal ha stor takk for at dikteren og dette diktet trekkes frem og presenteres for leserne. Diktet beskrives på en god måte, men grepet som hans gjennomgang bygger på yter ikke diktet rettferdighet. Selvfølgelig kan Metope brukes som «en veileder i pasientkommunikasjon». Dette diktet er imidlertid noe mye, mye mer også sett i en legepasient-relasjon. For å sette det inn i en enda større sammenheng handler diktet om den kjærligheten og det eksistensielle som alle mennesker har nedlagt i seg. Mælands grep blir reduksjonistisk, og dette blir tydelig i omtalen av dødsangst. Dødsangst er noe annet enn det store filosofiske spørsmålet om menneskets væren. Noen av oss er der noen ganger, som helsepersonell kan vi være der ofte. Det er et av vårt yrkes store privilegier. I palliativ sammenheng har jeg brukt dette diktet ofte, både overfor pasienter og pårørende og jeg har også brukt det i forelesninger for kolleger for å kunne beskrive den eksistensielle smerten.

I den selvvalgte prøveforelesningen min ved disputasen for dr.philos.graden ved Norges teknisk-naturvitenskapelige universitet 2013 om dødens estetikk brukt jeg diktet slik: «... dødens estetikk er en menneskets hjelper i forhold til den store eksistensielle utfordringen at en dag er det over. Jeg pleier å si og jeg mener det, at mitt livs privilegium har vært å ha orkesterplass til det største drama vi kan oppleve; i det ene øyeblikket er mennesket og i det neste er det ikke. Et av de sterkeste utrykk for dette i norsk poesi finner vi det monumentale diktet Metope av Olaf Bull. Etter min mening er dette det vakreste kjærlighetsdikt vi har. Men midt i diktet kommer den eksistensielle smerten...»

Jeg refererte her til det som Mæland kaller den fjerde strofen og i prøveforelesningen fortsatt jeg slik: «Sterkere og sårere kan ikke den eksistensielle smerten beskrive, slik stiller poeten det store spørsmålet, enkelt og rystende. Det er dette livet handler om, dobbeltheten. Alt det gode og vakre vi har og som med ett blir borte. Hos oss alle, mer eller mindre til overflaten, ligger denne erkjennelsen. Jo oftere og nærmere den er oss, desto mer kjennes den og må lindres.»)

Dette innlegget er ikke ment som en kritikk av Mælands artikkel, men mer et supplement. Jeg synes grepet $i$ artikkelen ble vel instrumentelt i forhold til diktets storhet og den betydning det kan ha for hver enkelt av oss, både som fagpersoner og mennesker.

\section{Kjell Erik Strømskag}

Kjell.Erik.Stromskag@helse-mr.no

Kjell Erik Strømskag (f. 1952) er spesialist i anestesiologi ved Molde sjukehus, dr.med. og dr.philos. og professor II ved Norges teknisk-naturvitenskapelige universitet.

Ingen oppgitte interessekonflikter

\section{Litteratur}

1. Mæland NF. Olaf Bulls dikt Metope - lest som terapeutisk samtale. Tidsskr Nor Legeforen 2016; 136: 1102-5.

\section{Re: Nedsatt syn hos barn og unge i Norge}

I en interessant artikkel om nedsatt syn hos barn og unge i Norge (1) er det satt søkelys på behovet i Norge for et øyemedisinsk register over barn og unge med nedsatt syn. Det ble nevnt det beklagelige faktum at vårt tidligere eksisterende medisinske register, Det norske blindekartotek, ble nedlagt i 1995. Som tidligere leder av Blindekartoteket vil jeg knytte noen kommentarer til artikkelen.

I artikkelen som søker kartlagt synsvansker og årsaker til synsnedsettelse hos barn og unge basert på synspedagogisk registrering, 
er resultatene sammenlignet med data fra de medisinske registre i våre naboland. Det ville være nærliggende å foreta en sammenligning med våre egne data som forelå og ble presentert i Blindekartotekets oversikter, siste gang ved kartotekets nedleggelse i 1995. Blindekartotekets siste rapport ble sendt til alle landets øyeleger og øyeavdelinger samt til andre institutter. En engelsk versjon ble sendt til institutter og avdelinger i utlandet, og mange positive tilbakemeldinger ble mottatt.

I kartoteket er det innsamlede data fra alle aldersgrupper (2). Totalt blinde og svaksynte i live per 1.1.1995 var 10 077, hvorav 668 var under 20 år. Hele datamaterialet utgjorde ca. 25000 blinde og svaksynte innsamlet gjennom de 27 år som Blindekartoteket var i virksomhet. På grunn av svakheten ved øyelegenes mangelfulle meldinger ble kartotekets data supplert fra andre kilder, først og fremst fra Blindeforbundet, som Blindekartoteket hadde et godt samarbeid med. Ca. $40 \%$ av tilgangen til kartoteket ble fanget opp på denne måten.

En tragisk beslutning om nedleggelse av Blindekartoteket ble gjort av daværende helsedirektør. Saksbehandlingen må betegnes som skandaløst dårlig. Beslutningen om nedleggelse var forhastet og bygd på sviktende premisser. De nærmere omstendigheter omkring nedleggelsen er redegjort for i rapporten (2).

Blindekartoteket, da det var i funksjon, var ganske enestående i verden med obligatorisk melding av alle blinde og svaksynte. En stor svakhet var likevel svikten i meldinger fra øyelegene, til tross for at lovfestet meldeplikt var innført. Det store materialet som er lagret i Blindekartoteket, vil fortsatt være en verdifull basis ved en eventuell gjeninnføring av en øyemedisinsk registrering. Databasen med de identifiserbare meldinger ble overført til Statens helseundersøkelser og Riksarkivet.

Anbefalingene fra Haugen og medarbeidere om gjenopprettelse av et øyemedisinsk register i Norge bør støttes fullt ut. Registrering er uomgjengelig nødvendig for bekjempelse av blindhet og svaksynthet. Man må bare håpe at vanskelighetene som foreligger $\mathrm{i}$ dag, kan overvinnes.

\section{Egill Hansen}

egillh@online.no

Egill Hansen (f. 1929) er spesialist i øyesykdommer og tidligere leder av Blindekartoteket.

Ingen oppgitte interessekonflikter.

\section{Litteratur}

1. Haugen $\mathrm{OH}$, Bredrup C, Rødahl E. Nedsatt syn hos barn og unge i Norge. Tidsskr Nor Legeforen 2016: 136: 996-1000.

2. Hansen E, red. Det norske blindekartotek 1968-1995. Status og oppsummering. Rapport. Oslo: Det norske blindekartotek, 1996.

\section{O.H. Haugen og medarbeidere svarer:}

Vi vil takke tidligere leder for Blindekartoteket Egill Hansen for kommentar til vår artikkel om nedsatt syn hos barn og unge (1) og hans støtte til vårt anliggende. Han etterlyser en sammenlikning av dataene fra studien med data som forelå i Blindekartoteket. I vår artikkel har vi referert grundig til NORDSYN-studien, som jo besto av data samlet fra synsregistrene i Norge, Danmark, Finland og Island. I artiklene fra denne studien ble det vist at funnene fra disse fire landene var ganske samstemte, både når det gjaldt fordeling mellom svaksynte og blinde (2), fordeling på diagnosegrupper (3) og etiologiske faktorer (4). I og med NORDSYN-studien er således data fra Det norske blindekartotek også presentert. Dataene fra vår studie samsvarer, som nevnt i vår artikkel, godt både med NORDSYN-dataene og den tilsvarende svenske studien.

\section{Olav H. Haugen}

olav.haugen@helse-bergen.no

Cecilie Bredrup

Eyvind Rødahl

Olav H. Haugen (f. 1955) er spesialist i øyesykdommer, professor og seksjonsoverlege ved Øyeavdelingen, Haukeland universitetssykehus og Universitetet i Bergen.

Ingen oppgitte interessekonflikter.

Cecilie Bredrup (f. 1973) er spesialist i øyesykdommer og forsker ved Øyeavdelingen, Haukeland universitetssykehus.

Ingen oppgitte interessekonflikter.

Eyvind Rødahl (f. 1957) er spesialist i øyesykdommer og professor ved Øyeavdelingen, Haukeland universitetssykehus og Universitetet i Bergen. Ingen oppgitte interessekonflikter.

\section{Litteratur}

1. Haugen $\mathrm{OH}$, Bredrup C, Rødahl E. Nedsatt syn hos barn og unge i Norge. Tidsskr Nor Legeforen 2016: 136:996-1000.

2. Riise R, Flage T, Hansen E et al. Visual impairment in Nordic children. I. Nordic registers and prevalence data. Acta Ophthalmol (Copenh) 1992; 70: 145-54.

3. Hansen E, Flage T, Rosenberg T et al. Visual impairment in Nordic children. III Diagnoses. Acta Ophthalmol (Copenh) 1992; 70: 597-604.

4. Rosenberg T, Flage T, Hansen E et al. Visual impairment in Nordic children. II. Aetiological factors. Acta Ophthalmol (Copenh) 1992; 70: 155-64. 